\title{
Iranian EFL Learners' Grammatical Knowledge: Effect of Direct and Metalinguistic Corrective Feedback
}

\author{
Zahra Kheradmand Saadi ${ }^{1} \&$ Mahboobeh Saadat ${ }^{2}$ \\ ${ }^{1}$ Department of Foreign Languages and Linguistics, Shiraz University, Shiraz, Iran \\ 2 Department of Foreign Languages and Linguistics, Shiraz University, Shiraz, Iran \\ Correspondence: Mahboobeh Saadat, Department of Foreign Languages and Linguistics, Shiraz University, \\ Shiraz, 7194685115, Iran. Tel: 8-713-613-4537. E-mail: msaadat@rose.shirazu.ac.ir
}

\author{
Received: April 23, 2015 Accepted: June 26, 2015 Online Published: July 26, 2015 \\ doi:10.5539/elt.v8n8p112 URL: http://dx.doi.org/10.5539/elt.v8n8p112
}

\begin{abstract}
The present study was conducted to compare the impact of direct and metalinguistic written corrective feedback on Iranian EFL learners' grammatical knowledge. The participants were a convenient sample of students in two intact writing classes. The instruction provided in both groups was similar; however, the students in one group received direct feedback and the students in the other group received metalinguistic feedback in the form of error codes on writing accuracy (i.e., grammar, vocabulary, and punctuation) of their in-class written texts. Moreover, all the students took a grammar test serving as pre- and posttests before and after the treatment. In addition to the computation of gain scores, descriptive statistics and a mixed between-within subjects ANOVA were run to analyze the data. Descriptive statistics revealed that the grammatical knowledge of the learners in both groups developed as a result of the two types of feedback; nonetheless, there was not a statistically significant difference between the students' performance on the grammar test before and after the treatment. Furthermore, although the direct feedback seemed to be more effective in improving grammatical knowledge, no statistically significant difference was found between the two groups' gain scores on the grammar test. Accordingly, it was concluded that either of the feedback types may be employed to effectively develop EFL learners' knowledge of grammar.
\end{abstract}

Keywords: corrective feedback, direct feedback, EFL, grammatical knowledge, metalinguistic feedback

\section{Introduction}

The extent to which corrective feedback on linguistic errors can play a role in learning the target language has been an issue of interest to researchers since it is one of the framework options involved in form focused instruction (FFI) (Ellis, 2008). Ellis considers it as a type of FFI which is available to teachers and researchers for instruction and investigation of its effects on second language acquisition. According to Sheen and Ellis (2011, p. 593), "Corrective feedback refers to the feedback that learners receive on the linguistic errors they make in their oral or written production in a second language".

The effectiveness of corrective feedback has been debated since Truscott (1996) claimed that it is ineffective and even harmful and, thus, should be abandoned. Truscott $(1996,1999, \& 2009)$ has been the most vocal opponent of error correction, and has encouraged further and more methodologically appropriate research in this regard. He also noted that regardless of learners' perceptions that corrective feedback is useful, it should not be given. He insisted that even though students may demand or expect corrective feedback, teachers should refrain from providing it.

Contrary to Truscott's view regarding ineffectiveness of corrective feedback, cognitive theorists believe that corrective feedback plays an important role in language learning (e.g., Ellis, 2009; Sheen \& Ellis, 2011). They argue that providing corrective feedback while learners are involved in meaning-focused activities facilitates acquisition (Sheen \& Ellis, 2011). Moreover, in education, feedback is regarded as a significant factor encouraging and enhancing learning (Lee, 2008; Ferris \& Roberts, 2001). According to Ellis, "there is clear evidence that corrective feedback contributes to learning" (2008, p.885).

\section{Literature Review}

Different types of corrective feedback have been enumerated and employed in the literature; however, since the focus of the present study is on direct and metalinguistic corrective feedback, provision of definitions of the two 
types seems to be in order. Direct feedback occurs when the correct form is given instead of the incorrect form; whereas in metalinguistic feedback, some type of metalinguistic clue is provided. Use of error codes is one type of this feedback and it occurs when an error is identified with the use of error codes and abbreviations.

The role of (different types of) corrective feedback in language learning has already been investigated by a considerable number of researchers. Cohen and Robin are known as the first researchers who addressed this issue in 1976. They conducted an error analysis of verb forms of written drafts of three advanced ESL university students. Their goal was to investigate the effect of error correction done by the teachers on the accuracy and eradication of errors. They found no relationship between the provision of the teacher feedback and improvement of the students' accuracy in writing. The study showed that correction in written drafts was neither systematic nor enlightened enough to influence the students' accuracy.

Similarly, as mentioned before, Truscott (1996) not only rejected the efficacy of teacher feedback but also stated that this type of feedback should be abandoned since it is harmful. In addition, he believed that grammar correction limited the students to surface level structures of their written drafts, diverged the students from development of ideas and deviated their attention from focusing on the content and organization of their writings. Furthermore, Fazio (2001), in an experimental study, investigated the effect of providing the minority and majority students with corrections, commentaries and a combination of correction and commentary. The researcher's goal was to see the effect of these types of feedback on the journal writing accuracy of the students. The two groups were randomly assigned to different feedback conditions. For both student groups, results indicated no significant difference in accuracy due to feedback conditions.

On the contrary, Lalande (1982) showed that corrective feedback given by teachers helped students to improve the accuracy of their language skills. Yet in another study, Havranek (2002) investigated the relationship between feedback and acquisition. Eight classes, with a total of 207 students, were observed and the feedback episodes were transcribed. Class-specific tests, in which there were many task types that the students were required to complete, were administered to the students. The tests included as many errors from the feedback episodes as possible. There were two groups participating in the study, one involved in feedback episodes and the other not. The results of the tests suggested that more than half of the time, the students who made mistakes and were then corrected could use the structure correctly on the test.

Moreover, Chandler's (2003) study can be referred to as a study the result of which supported error correction. Chandler used the experimental and control groups' data and showed that students' correction of grammatical and lexical errors between assignments reduced such errors in their subsequent writing. Furthermore, the findings revealed that both direct correction and simple underlining of errors were more effective than describing the type of error. In fact, direct correction was effective in the production of accurate revisions. Finally, it was found that both students and teachers preferred direct correction since it was an easy and fast approach to error correction.

In a much similar vein, Sheen (2007) compared direct and indirect metalinguistic written corrective feedback on the learners' use of articles. Three groups were employed to conduct the study: a direct-only correction group, a direct metalinguistic correction group, and a control group. The results showed that both treatment groups performed much better than the control group, but the direct metalinguistic group outperformed the direct-only correction group in the delayed posttests. In other words, direct and metalinguistic types of feedback were effective in increasing accuracy in the learners' use of articles in subsequent writings completed immediately after the written corrective feedback treatment, but the metalinguistic written corrective feedback proved more effective than the direct written corrective feedback in the long term.

Furthermore, Ellis (2008) speculated that metalinguistic written corrective feedback forces learners to formulate some kind of rule about the particular grammatical feature on which they have received feedback and then they may use this rule; nonetheless, it takes time for the learners to use the rule effectively. On the other hand, direct feedback might have an immediate effect, but learners soon forget the correction; however, if they have learned the rule, it may have a long term effect on learners' ability to avoid the errors. Ellis (2009) further added that direct feedback has the advantage that it provides learners with explicit guidance about how to correct their errors.

Through a mixed method design, Paiva (2011) studied the Brazilian EFL teachers' beliefs about grammar-based corrective feedback on L2 writing and the relatedness of their beliefs to their pedagogical practices in their classes. The teachers in the study believed that

Grammar correction in L2 writing is necessary in writing classes. Providing corrective feedback on learners' writing is time consuming but worthwhile. Grammar feedback on L2 writing does not necessarily help learners 
write well, but can help them write accurately. Grammar correction in L2 writing is useful because students expect it from teachers. (p. 41)

Pavia (2011) found that the teachers considered corrective feedback on grammar in writing classes a useful activity. However, empirical evidence regarding the effectiveness of grammar-based corrective feedback on L2 writing was not provided in the study. Thus, the researcher expressed doubts about whether grammar correction actually contributes to learners' writing development. In an attempt to shed more light on the issue, more recent studies have sought to provide empirical evidence regarding effectiveness of corrective feedback in improving writing accuracy and accurate use of grammatical structures.

To see the effect of corrective feedback in task-based grammar instruction, Rezaei and Derakhshan (2011) provided EFL learners with metalinguistic and recast feedback on the use of conditional and wish structures. The participants of the study were randomly assigned to two experimental groups, one group receiving metalinguistic feedback and the other receiving recast, and a control group who did not receive any type of feedback. The findings indicated that the two types of feedback were effective in task-based grammar instruction and helped the experimental groups to learn accurate use of conditionals and wish statements. Concerning the two types of feedback, it was shown that metalinguistic feedback was more effective than recast in improving the students' accurate use of grammatical structures. According to the researchers, in the Iranian EFL context, explicit types of feedback such as metalinguistic feedback are more productive and helpful compared to implicit types of feedback since they are more congruent with the Iranian students' needs and wants.

Furthermore, the effect of direct focused and unfocused written corrective feedback on the Iranian EFL learners' accurate use of two English definite and indefinite articles, 'a' and 'the' was investigated by Farrokhi (2012). The participants were divided into two experimental groups and a control group. One experimental group received focused feedback and the other one received unfocused feedback, and the control group received no feedback. The results showed that the two experimental groups outperformed the control group and the feedback given to the experimental groups improved the students' accurate use of English articles. Another finding of the study was superiority of the focused feedback over the unfocused feedback in improving accurate use of the two mentioned English articles.

Moreover, Daneshvar and Rahimi (2014) investigated the effect of two types of written feedback, direct focused and recast, on the Iranian EFL learners' writing grammatical accuracy. The participants of the study were 90 intermediate students who were divided into three groups: two experimental groups, who received either direct focused or recast feedback, and a control group who received no feedback. The results of the study showed that the two experimental groups outperformed the control group in improving the grammatical accuracy of their writing tasks. Moreover, it was revealed that recast was more effective than direct feedback in improving the EFL learners' writing accuracy.

Recently, Al Ajam (2015) examined the effect of written corrective feedback on Arab students' accurate use of English propositions. The participants were assigned to an experimental group who received written feedback on the accurate use of propositions and a control group who received general comment on their overall writing performance. The experimental group received feedback on the accurate use of ten propositions which were regularly confusing to the students. The results showed that the treatment given to the experimental group was effective in helping the students to use the mentioned English propositions accurately.

\section{Objectives and Research Questions}

Although some researchers have shown that metalinguistic feedback (Chaung, 2005; Ellis, 2008; Nagata, 1993; Sheen, 2007) and metalinguistic feedback with annotation tools (Yeh \& Lo, 2009) are effective types of feedback, some others believe that students may lack the necessary linguistic knowledge (Ferris \& Robert, 2001) and time (Ellis, 2008) to correct themselves. Additionally, regarding written corrective feedback, some early research revealed that corrective feedback given on students' writing had no effect on their development (e.g., Truscott, 1996, 1999, \& 2009); however, some other studies found that different types of corrective feedback provided on L2 writing can be effective (e.g., Chandler, 2003; Ellis, 2008; Sheen, 2007).

Nevertheless, the studies in which written corrective feedback was provided merely explored its effectiveness in improving learners' accuracy in their later written drafts, not their grammar knowledge. To add to the literature done on the issue and to fill the gap in the literature, this study tries to investigate whether corrective feedback, which is one of the options of FFI, can help learners to learn grammatical structures. Furthermore, it intends to explore how the two different types of feedback, direct and metalinguistic, may result in acquiring grammar knowledge. In so doing, the study addresses the following questions. 
1. Do direct and metalinguistic corrective feedback types result in Iranian EFL learners' grammar knowledge improvement?

2. Is there any significant difference between the effect of direct and metalinguistic written feedback on Iranian EFL learners' grammar knowledge?

\section{Method}

\subsection{Setting and Participants}

The present study was conducted at Shiraz University, Iran. A convenient sample of 29 (12 male, and 17 female) sophomore students majoring in English Language and Literature who had already enrolled in two intact classes took part in the study. The students in the two groups were of upper intermediate level command of the English language according to the results obtained from the Oxford Quick Placement Test (Oxford University Press, 2001). The students participated in two classes of Paragraph Writing each of which was held about two hours a week for a semester. Random assignment was used to assign the classes to different treatment groups, direct feedback $(\mathrm{N}=11)$ and metalinguistic feedback $(\mathrm{N}=18)$.

\subsection{Instruments}

\subsubsection{The Proficiency Test}

To make sure about the homogeneity of the two groups in terms of language proficiency before the treatments, the researchers used the information obtained through the administration of the Oxford Quick Placement Test (Oxford University Press, 2001).The test was designed by Oxford University and University of Cambridge Local Examination Syndicate. It consists of two parts (the first part intended for all the participants and the second for proficient participants) with a total of 60 multiple-choice questions on vocabulary, grammar, and cloze passages. The participants were required to answer all the questions in 30 minutes as it was stated in the manual. The reliability index of the test estimated through Cronbach's alpha appeared to be .86 which was quite satisfactory for the purpose of the study.

\subsubsection{The Grammar Test}

A grammar test, administered at the beginning and at the end of the course, functioned as both the pretest and posttest. The test, which was a sample practice TOEFL test, consisted of 40 multiple choice grammar items. The students were asked to do the test in 30 minutes. The pretest informed the researchers of the learners'grammar knowledge before the treatments, and the comparison between the participants' performances on the two test could show the efficiency of the treatments in improving the students' grammar knowledge. The reliability of the test estimated through Cronbach's alpha turned out to be .88 .

\subsection{Data Collection Procedure}

As mentioned before, the participants of the present study were the students of two intact paragraph writing classes. In the first session, in order to confirm the homogeneity of the two groups before the commencement of the treatment, the students in both classes were given the proficiency test and the grammar test. The results of these tests informed the researchers of the individual learners' language proficiency level and their grammatical knowledge. Then, the classes were randomly assigned to the direct group, who received instruction on writing and direct feedback on their errors, and the metalinguistic group, who received instruction on writing and metalinguistic feedback in the form of error codes.

During the course which consisted of 16 sessions, the students received instruction on principles of paragraph writing and techniques for developing paragraphs. In the initial sessions, the students in each group got familiar with the kind of feedback they were supposed to receive in the following sessions: i.e., direct or metalinguistic feedback. The students in both groups were asked to do a variety of activities and tasks including brainstorming, outlining, free writing, writing topic sentences, and 10 writing tasks following instruction on using different techniques of support or methods paragraph development. In other words, each session after the students were taught how to use a technique of support or a method of paragraph development, they wrote a paragraph using no more than 200 words on the assigned topic following the instructions provided. Afterwards, the students received corrective feedback on the accuracy of their assignments. The students in both groups were also supposed to revise their texts based on the feedback they had received and hand them in the next session. The revision of their first drafts was intended to help them notice the objectives and benefits of the type of feedback offered and employ the feedback to improve their written texts. At the end of the course, the students in both groups were given the same grammar test, which served as the posttest, as well as their final writing test. 


\subsection{Data Analysis Procedure}

Before initiation of the treatment, the two groups' scores on the proficiency test and the grammar pretest were compared using two independent samples t-tests to ensure the homogeneity of the two groups in terms of language proficiency and grammar knowledge. In order to detect any possible improvement in the students' grammar knowledge, the learners' performances on the pretest and posttest grammar test were compared. In fact, a mixed between-within ANOVA was run to answer the research questions. Subsequently, in order to do a more detailed analysis of the results of the study, the gain scores for the students' performances on the grammar pretest and posttest were also computed and compared using t-tests. It is worth mentioning that since three independent samples t-tests were supposed to be run in the study and this could increase the possibility of obtaining spuriously significant differences, Bonferroni adjustment was first applied $\left(\alpha_{\text {adjusted }}=\alpha / \mathrm{c}=.05 / 3=.0167\right)$ and the obtained p-values were compared with the adjusted $\alpha$ level.

\section{Results}

In this section, the results of the placement test which was administered to verify the homogeneity of the two classes in terms of the students' level of language proficiency are provided. Moreover, the results of detailed analyses of the grammar pre- and posttests are provided.

\subsection{Results of the Proficiency Test}

As mentioned before, a proficiency test (Oxford Quick Placement Test, 2001) was used before the treatment to examine the two groups' proficiency in English. To compare the proficiency scores of the students in the two groups, who appeared to be at the upper intermediate level (based on the placement test scoring scale), an independent-samples t-test was run. According to Table 1, there was no significant difference between the direct and metalinguistic groups' proficiency scores $(\mathrm{t}(27)=.65$, $\mathrm{Sig}=.51)$. This indicates the homogeneity of the two classes in terms of language proficiency before the intended treatments.

Table 1. Descriptive statistics for language proficiency scores of the direct and metalinguistic groups and results of independent-samples t-test

\begin{tabular}{llllllllll}
\hline Group & N & Mean & SD & Min & Max & Possible range & t & df & Sig. (two-tailed) \\
\hline Direct & 11 & 40.18 & 9.71 & 25 & 53 & $0-60$ & .659 & 27 & .516 \\
Metalinguistic & 18 & 37.78 & 9.43 & 18 & 52 & $0-60$ & & & \\
\hline
\end{tabular}

\subsection{Results of the Grammar Pretest}

Similarly, to investigate the homogeneity of the two groups with regard to their grammar knowledge, an independent-samples t-test was conducted. As Table 2 shows, there was not a significant difference between the scores of the direct and metalinguistic groups on the grammar pretest $(\mathrm{t}(27)=-1.50$, Sig $=.144)$ which indicated that the two groups of students possessed similar levels of grammar knowledge before the treatments started.

Table 2. Descriptive statistics for grammar pre-test scores of the direct and metalinguistic groups and results of independent-samples t-test

\begin{tabular}{llllllllll}
\hline Group & N & Mean & SD & Min & Max & Possible range & t & df & Sig. (two-tailed) \\
\hline Direct & 11 & 25.4 & 8.25 & 14 & 36 & $0-40$ & -1.50 & 27 & .144 \\
Metalinguistic & 18 & 29.3 & 5.64 & 17 & 37 & $0-40$ & & & \\
\hline
\end{tabular}

\subsection{Comparison of the Effects of Direct and Metalinguistic Feedback on the Improvement of the Students' Grammar Knowledge}

In order to assess the impact of the two types of feedback on the students' grammar knowledge, a comparison was made between the direct and metalinguistic groups' scores on the pretest and posttest grammar test. As the results displayed in Table 3 show, both groups appeared to have made improvement as a result of the type of feedback offered. 
Table 3. Descriptive statistics for pretest and posttest grammar scores

\begin{tabular}{lllllllll}
\hline & Grammar test & Group & N & Mean & SD & Min & Max & Possible range \\
\cline { 2 - 8 } & Pre-test & Direct & 11 & 25.4 & 8.25 & 14 & 36 & $0-40$ \\
Descriptivestatistics & & Metalinguistic & 18 & 29.3 & 5.64 & 17 & 37 & $0-40$ \\
& \multirow{2}{*}{ Post-test } & Direct & 11 & 28.0 & 7.58 & 17 & 38 & $0-40$ \\
& & Metalinguistic & 18 & 30.3 & 5.23 & 17 & 37 & $0-40$ \\
\hline
\end{tabular}

However, in order to statistically examine the two groups' performances, a mixed between-within subjects analysis of variance (ANOVA) was conducted. At first, preliminary assumption testing was conducted to check for homogeneity of inter-correlations and homogeneity of variances; no serious violations were observed. As the results in Table 4 indicate, there was not a significant interaction between time and group (i.e. different interventions) (Wilk's Lambda $=.948, \mathrm{~F}(1,27)=1.48$, Sig=.234, Partial eta squared=.052), meaning that in the course of time the two experimental groups'development in grammar knowledge did not show much difference. As for the impact of the two types of intervention, the effect was not significantly different $(F(1,27)=1.68$, $\mathrm{Sig}=.206$, Partial eta squared=.059), suggesting no difference in the effectiveness of the two feedback types in improving the students' grammar. However, there was a significant main effect for time (Wilk's Lambda=.776, F $(1,27)=7.80, \mathrm{Sig}=.009$, Partial eta squared $=.224)$. This shows that both groups significantly improved their grammar knowledge over time and the effect of time, as indicated by the effect size, was large (Cohen, 1988).

Table 4. Results of mixed between-within subjects ANOVA for pretest and posttest grammar scores

\begin{tabular}{|c|c|c|c|c|c|c|c|}
\hline \multicolumn{8}{|c|}{ Mixed-between-within ANOVA } \\
\hline \multirow{3}{*}{$\begin{array}{l}\text { Multivariate } \\
\text { tests (of within } \\
\text { subject effect) }\end{array}$} & Effect & $\begin{array}{c}\text { Wilk's Lambda } \\
\text { value }\end{array}$ & $\mathbf{F}$ & Hypothesis df & Error df & Sig. & $\begin{array}{c}\text { Partial Eta } \\
\text { Squared }\end{array}$ \\
\hline & Time & .776 & 7.80 & 1 & 27.000 & .009 & .224 \\
\hline & Time*Group & .948 & 1.48 & 1 & 27.000 & .234 & .052 \\
\hline \multirow{2}{*}{$\begin{array}{c}\text { Tests of } \\
\text { between-subjec } \\
\text { t effect }\end{array}$} & \multirow[t]{2}{*}{ Group } & $\begin{array}{l}\text { Type III Sum } \\
\text { ofSquares }\end{array}$ & df & Mean Square & $\mathrm{F}$ & Sig. & $\begin{array}{c}\text { Partial Eta } \\
\text { Squared }\end{array}$ \\
\hline & & 131.7 & $1(27)$ & 131.7 & 1.68 & .206 & .059 \\
\hline
\end{tabular}

A comparison between the improvements in the grammar knowledge of the students in the two groups over time is graphically depicted in Figure 1. As it is shown in the figure, the students in the direct group showed a rather better performance than their counterparts in the metalinguistic group over time; however, the results displayed in Table 4 showed no statistical difference between the performances of the students in the two groups in terms of grammar knowledge. 


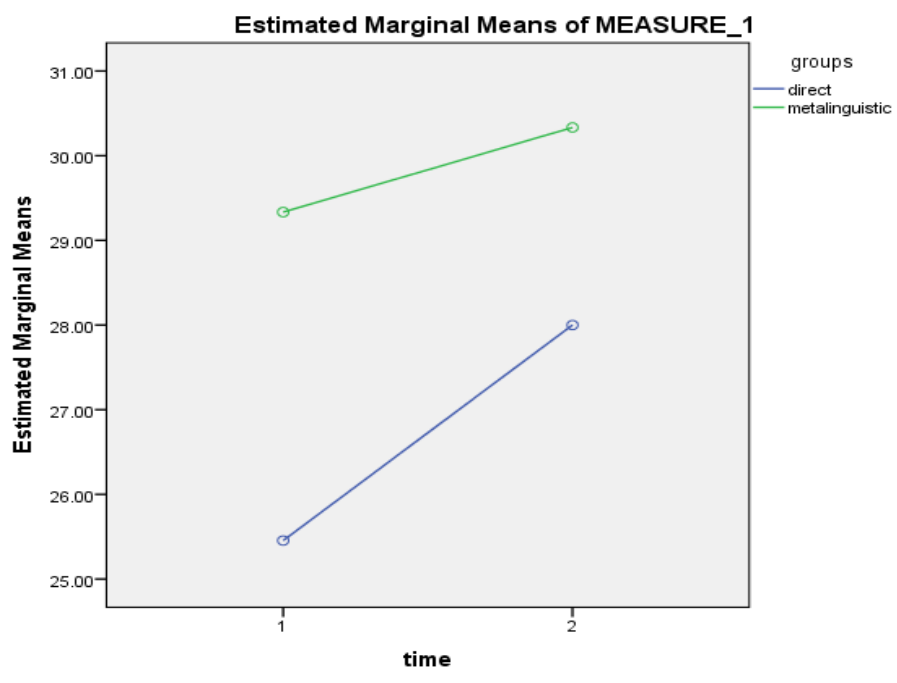

Figure 1. Comparison of pretest (1) and posttest (2) grammar scores of the direct and metalinguistic groups

In order to scrutinize the issue further, gain scores of individual students in both groups from pretest to posttest grammar test were computed and compared using an independent-samples t-test. As the results in Table 5 indicate, the mean grammar gain score of the students in the direct group $(\mathrm{M}=.199, \mathrm{SD}=.253)$ was higher than the mean gain score of the students in the metalinguistic group $(\mathrm{M}=.063, \mathrm{SD}=.268)$; however, there was not a statistically significant difference between the mean gain scores of the two groups ( $\mathrm{t}(27)=1.34$, Sig $=.190)$. This suggests that the direct and metalinguistic feedback on the students' writing tasks resulted in rather similar improvement in the grammar knowledge of both groups.

Table 5. Descriptive statistics for the direct and metalinguistic groups' grammar gain scores and results of independent-samples t-test

\begin{tabular}{lllllll}
\hline Group & N & Mean & SD & t & df & Sig. (two-tailed) \\
\hline Direct & 11 & .199 & .253 & & & \\
Metalinguistic & 18 & .063 & .268 & 1.34 & 27 & .190 \\
\hline
\end{tabular}

\section{Discussion and Conclusion}

In this section, at first, the two research questions posed earlier are restated and the results of the study are discussed in the light of the literature. Finally, conclusions are drawn, and pedagogical implications of the study and suggestions for further research are offered.

Research question one: Do the direct and metalinguistic corrective feedback types offered to the two groups result in the Iranian EFL learners' grammar knowledge improvement?

According to the results, the participants in both groups gained higher grammar scores after receiving the type of feedback presented in their groups. Therefore, both types of feedback similarly resulted in the development of the learners' grammar knowledge. The results of the study were in line with the studies which showed that corrective feedback was effective in furthering language learning (Chandler, 2003; Ellis, 2008; Ellis, 2009; Havranek, 2002; Lalande, 1982; Rezaie \& Derakhshan, 2011; Sheen, 2007) or recommended form-focused correction as a valuable instructional approach (Paiva, 2011). Moreover, the results supported the findings of Daneshvar and Rahimi (2014) and Al Ajam's (2015) studies which showed that written grammar-based feedback on the students' writing tasks helped them to improve their grammatical accuracy in subsequent writing tasks. What's more, the present study showed that feedback on grammar improved the students' accurate use of grammatical structures; this lends further support to the conclusions made by Rezaei and Derakhshan (2011) and Farrokhi (2012), also done in the Iranian context, which showed that providing the students with feedback on some specific grammar points helped them to use the grammaratical structures accurately. 
However, the results are in contrast to some early researches which revealed that corrective feedback given to the students' writing had no effect or negative effect on their development (Cohen \& Robin, 1976; Truscott, 1996, 1999, 2009). It is worth noting that the researchers who found feedback ineffective admitted that the feedback they provided was not systematic enough to result in language learning (Cohen \& Robin, 1976; Fazio, 2001); whereas, the feedback provided in the present study was quite systemic in that the students in either group, based on the kind of errors, similarly received the respective type of corrective feedback after each task they did. Moreover, the students in both groups were supposed to revise their texts regardless of the treatment they received. It is suggested that revision was effective in improving the learners' grammar knowledge since revision is regarded as an important activity that helps students to benefit from the feedback they receive (Li \& Lin, 2007).

Research question two: Is there any significant difference between the effect of direct and metalinguistic written feedback on Iranian EFL learners' grammar knowledge?

Descriptive statistics showed that the students who received direct feedback gained higher (gain) scores on the grammar test than the group who received metalinguistic feedback; however, the statistical analyses done through mixed-between subjects ANOVA and the t-test showed that there was not a statistically significant difference between the two groups in terms of their grammar scores. Thus, the answer to the second research question is that there was no significant difference in the effectiveness of the types of feedback that the students received. This finding is in contrast to the studies which showed that either direct or metalinguistic feedback was more effective in language learning (Ellis, 2009; Ferris \& Roberts, 2001; Sheen, 2007). However, the obtained result may be accounted for by considering the fact that both groups received systematic corrective feedback; thus, both groups rather equally improved their grammar knowledge. Another explanation for the obtained result would be that direct and metalinguistic feedback provided were more in line with the students' needs since, as Rezaei and Derakhshan (2011) claimed, explicit types of feedback are more effective than implicit ones for Iranian students.

In sum, the results of the study revealed that corrective feedback on Iranian EFL learners' written drafts improved their grammar knowledge. However, the findings indicated that there were no significant differences between the grammar (gain) scores of the students who received direct feedback and those who received metalinguistic feedback. This implies that providing systematic direct and metalinguistic feedback can similarly result in the development of learners' grammar knowledge. Based on the results, it may be suggested that EFL writing teachers who intend to focus upon developing learners' grammar competency may equally benefit from direct or metalinguistic feedback at their discretion. Nevertheless, the results should be interpreted with caution since the study suffered from a couple of shortcomings. The first shortcoming concerns the design of the study: the two groups received treatment and there was no access to a third group to serve as the control group. Another limitation has to do with the small size of the sample and, thus, the rather small variation observed in the performances of the students in the two groups which may have adversely affected the results. Therefore, further studies may be conducted with a larger sample including a control group so as to verify the results of the present study.

\section{References}

Al Ajam, A. (2015). The Effect of Written Corrective Feedback on Omani Students' Accuracy in the Use of English Prepositions. Advances in Language and Literary Studies, 6(1), 61-71.

Chandler, J. (2003). The efficacy of various kinds of error feedback for improvement in the accuracy and fluency of L2 student writing. Journal of second language writing, 12(3), 267-296. http://dx.doi.org/10.1016/S1060-3743(03)00038-9

Chuang, W. (2005). The effects of four different types of corrective feedback on EFL students' writing in Taiwan. Retrieved, November 3, 2013 from the ERIC database. (EJ1032499)

Cohen, A. D., \& Robbins, M. (1976). Toward assessing interlanguage performance: The relationship between selected errors, learners' characteristics, and learners' expectations. Language Learning, 26(1), 45-66. http://dx.doi.org/10.1111/j.1467-1770.1976.tb00259

Cohen, J. W. (1988). Statistical power analysis for the behavioral sciences $\left(2^{\text {nd }}\right.$ ed.). Hillsdale, NJ: Lawrence Erlbaum Associates.

Daneshvar, E., \& Rahimi, A. (2014). Written corrective feedback and teaching grammar. Procedia, 136, 217-221.

Ellis, R. (2008). The study of second language acquisition ( $2^{\text {nd }}$ ed.). New York: Oxford University Press. 
Ellis, R. (2009). Corrective feedback and teacher development. L2 Journal, 1, 3-18. Retrieved January 15, 2015, from http://repositories.cdlib.org/uccllt/12/vol1/iss1/art2/

Farrokhi, F. (2012). The Effects of Direct Written Corrective Feedback on Improvement of Grammatical Accuracy of High- proficient L2 Learners. World Journal of Education, 2(2), 49-57.

Fazio, L. (2001). The effect of corrections and commentaries on the journal writing accuracy of minority -and

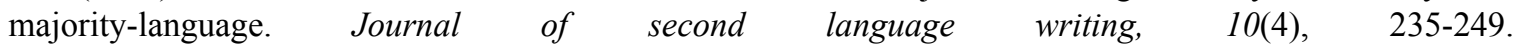
http://dx.doi.org/10.1016/S1060-3743(01)00042

Ferris, D., \& Roberts, B. (2001). Error feedback in L2 writing classes: How explicit does it need to be? Journal of Second Language Writing, 10, 161-184. http://dx.doi.org/10.1016/S1060-3743(01)00039-x

Havranek, G. (2002). When is corrective feedback most likely to succeed? International Journal of Educational Research, 37(3), 255-270. http://dx.doi.org/10.1016/S0883-0355(03)00004-1

Lalande, J. F., II. (1982). Reducing composition errors: An experiment. Modern Language Journal, 66(2), 140-149.

Lee, I. (2008). Student reaction to teacher feedback in two Hong Kong secondary classrooms. Journal of Second Language Writing, 17, 144-164.

Nagata, N. (1993). Intelligent computer feedback for second language instruction. The Modern Language Journal, 77(3), 330-339. http://dx.doi.org/ 10.1111/j:1540-4781.1993.tb01980.x

Oxford University Press \& University of Cambridge Local Examinations Syndicate. (2001). Oxford Quick Placement Test (Version 1). Retrieved from http://www.vhs. aschaffenburg.de/documents

Paiva, K. (2011). Brazilian English as foreign language teachers' beliefs about grammar-based feedback on L2 writing (Unpublished Master Dissertation). Iowa State University, The USA.

Rezaei, S., \& Derakhshan, A. (2011). Investigating Recast and Metalinguistic Feedback in Task-based Grammar Instruction. Journal of Language Teaching and Research, 2(3), 655-663. http://dx.doi.org/10.4304/jltr.2.3.655-663

Sheen, Y. (2007). The effect of focused written corrective feedback and language aptitude on ESL learners' acquisition of articles. TESOL Quarterly, 41, 255-283. http://dx.doi.org/10.1002/j.1545-7249.2007.tb00059.x

Sheen, Y., \& Ellis, R. (2011). Corrective feedback in language teaching. In E. Hinkle (Ed.), Handbook of research in second language teaching and learning (pp. 593-609). New York: Taylor \& Francis.

Truscott, J. (1996). The case against grammar correction in L2 writing classes. Language Learning, 46(2), 327-369. http://dx.doi.org/10.1111/j.1467-1770.1996.tb01238.x

Truscott, J. (1999). The case for "the case for grammar correction in L2 writing classes": A response to Ferris. Journal of Second Language Writing, 8, 111-122. http://dx.doi.org/10.1016/S1060-3743 (99)80124-6

Truscott, J. (2009). Arguments and appearances: A response to Chandler. Journal of Second Language Writing, 18 (1), 59-60. http://dx.doi.org/10.1016/j.jslw.2008.09.001

Yeh, S. W., \& Lo, J. J. (2009). Using online annotations to support error correction and corrective feedback. Computers and Education: An International Journal, 52(2), 882-892. http://dx.doi.org/10.1016/j.compedu.2008.12.014

\section{Copyrights}

Copyright for this article is retained by the author(s), with first publication rights granted to the journal.

This is an open-access article distributed under the terms and conditions of the Creative Commons Attribution license (http://creativecommons.org/licenses/by/3.0/). 